\title{
1 Aloe sp. leaf gel and water glass for municipal wastewater sludge treatment
}

2 and odour removal

Short title

4 Municipal wastewater sludge treatment and odour removal

5 Thameur Jaouadi ${ }^{1,2}<$ jawadithamr@yahoo.fr>

$6 \quad$ Mounir Hajji ${ }^{3}$ < hj.mounir@gmail.com>

$7 \quad$ Mariam Kasmi ${ }^{2 *}<$ mariam.kasmi@ certe.rnrt.tn>

$8 \quad$ Amjad Kallel ${ }^{4}<$ amjad.kallel@enis.tn>

$9 \quad$ Abdelwaheb Chatti ${ }^{2}<$ chatti_abdel@yahoo.fr>

Hichem Hamzaoui ${ }^{3}$ < mdmihi10@ gmail.com>

Adel Mnif ${ }^{3}<$ mnifinrst@gmail.com>

Chedly Tizaoui ${ }^{5}<$ c.tizaoui@ swansea.ac.uk>

Ismail Trabelsi² ${ }^{2}$ ismail.trabelsi@ certe.rnrt.tn>

${ }^{1}$ Office National de l'Assainissement (ONAS), Tunisia

${ }^{2}$ Laboratoire de Traitement et Valorisation des Rejets Hydriques (LTVRH), CERTE, Technopark of Borj-Cedria, 8020, Soliman, Tunisia

University of Carthage, Avenue de la Republique, PO Box 77, 1054 Amilcar, Tunisia Tunis -Tunisia

${ }^{3}$ Laboratoire de Valorisation des matériaux utiles; Centre national des sciences et recherche de matériaux University of Carthage, Tunis -Tunisia

${ }^{4}$ Laboratoire Eau-Energie-Environnement (3E), Sfax National School of Engineering, University of Sfax, PO Box 1173, 3038, Sfax, Tunisia

${ }^{5}$ College of Engineering, Bay Campus, Swansea University, Swansea SA1 8EN, UK

*Corresponding author: Kasmi M.

Laboratoire de Traitement et Valorisation des Rejets Hydriques (LTVRH), CERTE, Technopark of Borj-Cedria, 8020, Soliman, Tunisia, University of Carthage, Tunisia Tel: (+216) 22729 485, Fax: (+216) 79325 802; E-mail: mariam.kasmi@ certe.rnrt.tn 


\section{Abstract}

Aloe gel (Alg), which is a natural extract from the Aloe sp. plant, was evaluated in this study for its potential use as a bioflocculant to treat urban wastewater sewage sludge. The gel was used alone and combined with water glass, (WG) under controlled conditions in laboratory experiments. Alg was found effective to settle the flocculated sludge rapidly and remove distinctive unpleasant odours of the sludge as highlighted by GC/MS analysis. Furthermore, Alg was $\mathrm{pH}$ tolerant and had no effect in changing the $\mathrm{pH}$ of the wastewater. The optimum dose of Alg was 3\% at which a sludge volume index (SVI) of $45.4 \mathrm{ml} / \mathrm{g}$ was obtained within 30 minutes settling time. To enhance the treatment performances of Alg, WG was also evaluated as an alkali agent to further reduce the chemical oxygen demand (COD) and ammonia (NH4$\mathrm{N}$ ) in the wastewater. At equal doses of $3 \%$ of $\mathrm{WG}$ and $\mathrm{Alg}$ each, the combined treatment outcomes showed high turbidity and NH4-N removals of 83 and $89 \%$, respectively but the overall COD removal was at best $25 \%$. The settling rate of treated sludge with combined Alg/WG was very rapid giving an SVI of $25.4 \mathrm{ml} / \mathrm{g}$ within only 5 minutes.

Keywords: sewage sludge; Aloe sp. gel; water glass; turbidity; COD removal; odour removal. 


\section{Introduction}

In municipal wastewater treatment, sludge treatment accounts for about a third of the total wastewater treatment plant costs (Nowak 2006), making it one of the important treatment sections of the process. New cost-effective and environmentally friendly sludge treatment technologies are hence needed by wastewater undertakers. In Tunisia, where this study was carried out, the activated sludge process (AS) is the most used biological process for wastewater treatment and the solid-liquid separation of the sludge from the treated water remains a challenge due to overload resulting in poor quality of treated wastewater (Jemli et al. 2015). To enhance the performance of the secondary clarifiers, addition of organic and/or inorganic flocculants is widely practiced. The coagulants/flocculants used in wastewater to aid the separation of sludge can be either inorganic such as aluminium sulphate, or chemically synthetic organic flocculants such as polyacrylamide derivatives (Zahrim et al. 2010). Although these coagulants/flocculants have been successfully used for many decades in the water and wastewater sectors, there have been concerns about their environmental impacts, cost and the sustainability of over-extraction of raw materials, which are not renewable resources. The leaching of monomers from sludges treated with synthetic organic polymeric flocculants has also been highlighted as a significant barrier for the use of wastewater sludge in other areas such as agricultural applications (Abdelaal 2004). Therefore, demand for new coagulants/flocculants to improve the characteristics of the produced sludge to be safely disposed off or utilized in other sectors (e.g. land spraying) is increasing. In recent years, bioflocculants have emerged as potential substitutes to traditional inorganic and synthetic polymeric coagulants/flocculants because they are effective in treating water, generally nontoxic, harmless, less sensitive to $\mathrm{pH}$ changes, and are biodegradable (Giri et al. 2015; Liu et al. 2015; Liu et al. 2010). Bioflocculants such as Moringa seeds (Menkiti and Onukwuli 2010), Lablab purpureus peels (Shilpa et al. 2012), Moroccan cactus extract (Abid et al. 2009), dates 
seeds (AL-Sameraiy 2012) and Opuntia dillenii (Nougbode et al. 2013) have been investigated for turbidity removal providing removal percentages in the range 78 to $94 \%$. Moringa oleifera seed, maize and chitosan were also used in direct filtration of lake water and were successfully evaluated for turbidity and microorganism removal as reported by Mandloi et al. (2004). A widely reported Indian grown natural coagulant (Nirmali seeds), Okra seeds pod tips, sap, plant stalk, and roots have also been studied (Al—Samawi and Shokralla 1996). Al-Samawi and Shokralla (2006) have used okra extract to treat clay suspensions and have concluded that the okra extract was a powerful polyelectrolyte coagulant whether it was used as a primary and/or as a coagulant aid with alum. They also confirmed that the natural okra extract performed much better than alum at high turbidity waters. Aloe vera has also been used in water and wastewater treatment to remove suspended solids, turbidity, chemical oxygen demand, heavy metals and textile dyes (Adugna and Gebresilasie 2018; Lee et al. 2015). Aloe leaves are well known for their mucilaginous jelly, which is referred to as Aloe gel (Femenia et al. 1999; Hamman 2008). Aloe gel contains mainly monosaccharides such as glucose and mannose, vitamins, minerals, polysaccharides and phenolic compounds together with some organic acids (Hamman 2008; Mazzulla et al. 2012). In their study on textile wastewater, Adugna and Gebresilasie (Adugna and Gebresilasie 2018) reported that Aloe steudneri performed as polyacrylamides for treating the wastewater and suggested that this natural flocculant can substitute the synthetic flocculant. Nougbode et al. (2016) have also confirmed that leaf gels from several Aloe species could be used as natural flocculants for water treatment. Adsorption was suggested as the mechanism by which Aloe gel provides water treatment due to its high fibre content (Adugna and Gebresilasie 2018). In addition, other constituents of the gel such as glyco-aloe-modinanthrone and tannins are postulated to be responsible for the gel's coagulation property. Despite being effective to treat water, Aloe gel, similarly to other natural flocculants, could increase the residual organic matter in the treated water. According to literature, the chemical composition of Aloe plants 
largely depends on the species analysed but overall the organic matter can reach up to $81 \%$ of the mass of Aloe plants (Eugene et al. 2011; Radha and Laxmipriya 2015). In this study, Aloe gel was evaluated for the first time as a bioflocculant to enhance the gravity settling of municipal wastewater sludge. The study also highlights the increased performance of using Aloe gel in combination with sodium silicates to obtain faster settling velocities of the treated wastewater sludge. Several jar tests were carried out to select the optimal doses of Aloe gel and sodium silicates and the effects on $\mathrm{pH}$ changes and the volume of sludge produced.

\section{Materials and Methods}

\section{Sludge collection}

The sludge samples were collected in two $20 \mathrm{~L}$ plastic jerrycans from the wasted line of a secondary settling reactor of an activated sludge process of the municipal wastewater treatment plant (Chotrana II, Tunis, Tunisia). The Chotrana treatment plant serves a population equivalent to 400000 with a total wastewater flow of $110847 \mathrm{~m}^{3}$ per year and serves several industries (textile, slaughterhouse and Food wastewater). The average solids concentration in the sludge is $33 \mathrm{~g} / \mathrm{L}$. The sludge samples were immediately stored after collection in a fridge at $5^{\circ} \mathrm{C}$. In certain experiments, the $\mathrm{pH}$ of the sludge was adjusted using $1 \mathrm{M} \mathrm{NaOH}$ and $1 \mathrm{M} \mathrm{HCl}$ solutions.

\section{Preparation of Aloe sp. gel}

The Aloe sp. leaves were harvested in March 2018 from a two-year-old Aloe vera plant grown in the garden of the Biotechnology Center of Borj Cedria, Soliman, Tunisia. The gel was prepared as described by Kasmi et al. (2018). Briefly, the whole leaves were washed with a tap water and the spikes which were placed along their margins, were removed before slicing the leaf to separate the skin from the filet. The resulting filets were mixed and homogenized using a hand electric blender (Moulinex, model genuine). The gel was used freshly in each experiment immediately after its preparation. 


\section{Aloe sp. gel analysis}

Aloe gel composition in terms of fats, sugars, proteins and minerals contents was determined.

Fats assessment was performed according to the methodology reported by Hamman (2008). Sugars were assessed using Dubois protocol (Dubois et al. 1956). Proteins content was determined using Bradford methodology (Bradford 1976). As for minerals, phosphorus and magnesium concentrations were determined by means of colorimetric method using vanadomolybdic complex and atomic absorption. Calcium concentration was determined using EDTA method; zinc, copper, and iron assessments were performed using atomic adsorption method (Rodier et al. 2009). Sodium and potassium contents were determined by the flame photometer method.

\section{Preparation of water glass}

Water glass (i.e. sodium metasilicate $\left.\left(\mathrm{Na}_{2} \mathrm{SiO}_{3}\right)\right)$ was prepared by reacting Tunisian silica sand $\left(\mathrm{SiO}_{2}>99 \%\right)$ with sodium carbonate, $\mathrm{Na}_{2} \mathrm{CO}_{3}(>99 \%$, Honeywell) in a $1: 1 \mathrm{M}$ ratio at temperatures between 1200 and $1300^{\circ} \mathrm{C}$ as indicated by Bouaoun et al. (2017).

\section{Coagulation and flocculation process}

The coagulation and flocculation tests were carried out in a jar apparatus equipped with four steel paddles. The doses of the Aloe gel varied according to the values 1, 3, 5 and $7 \%(\mathrm{v} / \mathrm{v})$ of sludge. The coagulation experiments were performed using a modified protocol as described by Patil and Hugar (2015). The coagulation step was done at high speed of $200 \mathrm{rpm}$ for $2 \mathrm{~min}$ followed by the flocculation step at $50 \mathrm{rpm}$ for $30 \mathrm{~min}$. The settling time was set to $60 \mathrm{~min}$ after flocculation.

Settling experiments were made using a glass column $(46 \mathrm{~cm}$ high and $7.8 \mathrm{~cm}$ in diameter) in which the height of the liquid/sludge interface was recorded at regular time intervals (Zodi et al. 2009). The effect of $\mathrm{pH}$ on sludge settleability was also studied using initial $\mathrm{pH}$ values of 7 , 11,12 and 13 adjusted by $1 \mathrm{M} \mathrm{NaOH}$ solution. 
152 To calculate the flocculating rate of Aloe gel, Kaolin clay was used to make suspensions at 5

153

154 $\mathrm{g} / \mathrm{L}$ in which, Alg was added and stirred for $2 \mathrm{~min}$. After settling for $1 \mathrm{~min}$, the absorbance at a wavelength of $550 \mathrm{~nm}$ of the supernatant sample was measured by a spectrophotometer UV/VIS Lambda 25 (PerkinElmer). The flocculating rate was calculated according to Equation (1) (Liu et al. 2010), where $A_{1}$ is the absorbance of the supernatant sample at $550 \mathrm{~nm}$ and $A_{0}$ is the absorbance of the control at $550 \mathrm{~nm}$.

Flocculating rate $=\left(\mathrm{A}_{0}-\mathrm{A}_{1}\right) / \mathrm{A}_{0} \times 100 \%$

\section{Analytical methods}

The solution suspended solids (SS) and volatile suspended solids (VSS) were measured according to the standard methods described by Rodier et al. (2009). The total organic carbon (TOC) was measured using a total carbon analyzer Shimadzu TOC 5050. The total nitrogen and phosphorous contents were determined following the standard methods proposed by Rodier et al. (2009). The $\mathrm{pH}$, conductivity $(\mathrm{mS} / \mathrm{cm})$ and total dissolved solids (TDS) (g/L) of each sample were determined using a multi-parameter instrument (C860, Consort bvba, Belgium). Chemical oxygen demand (COD) values were measured by the potassium dichromate colorimetric method using an open reflux system (Rodier et al. 2009). Ammoniacal nitrogen was determined according to the NF T90-15 method (AFNOR). Sludge settling ability is expressed by means of the sludge volume index (SVI) which is often recommended for the characterization of the sludge formation (Kallel et al. 2017; Tchobanoglous et al. 2003; Zodi et al. 2009). The SVI is defined by Equation (2).

$\mathrm{SVI}=\frac{\mathrm{H}_{30}}{\mathrm{H}_{0} \mathrm{SS}} 1000(\mathrm{ml} / \mathrm{g})$

where $\mathrm{H}_{30}$ is the sludge height after 30 min settling $(\mathrm{cm}), \mathrm{H}_{0}$ the initial height of the sludge in the settling column $(\mathrm{cm})$ and SS is the initial sludge concentration after treatment $(\mathrm{g} / \mathrm{L})$.

\section{GC-MS analysis VOCs}


Volatile organic compounds (VOCs) were analyzed using a headspace (TELEDYNE TEKEMAR HT3TM) coupled with an Agilent GC-MS system (GC with 7890A, mass detector 5975C with Triple-Axis, insert XL MSD). A $30 \mathrm{ml}$ headspace vial was used for incubation of the sample performed during $30 \mathrm{~min}$ in headspace oven at $50^{\circ} \mathrm{C}$, then transferred in a heated line at $85^{\circ} \mathrm{C}$ to avoid condensation of VOCs and injected in the GC inlet for $2 \mathrm{~min}$. A HP-5 ms (5 \% phenylmethylsiloxane) column (Agilent 19091S-433: 2169.66548) was used (30 m X 250 $\mu \mathrm{m} \mathrm{X} 0.25 \mu \mathrm{m})$ at $1.6 \mathrm{ml} / \mathrm{min}$ flow with helium N60 (99.9999\%) as carrier gas and the run was performed over $25 \mathrm{~min}$. The temperature programme of the oven was: $70^{\circ} \mathrm{C}$ for $2 \mathrm{~min}$, then, $230^{\circ} \mathrm{C}$ for $20 \mathrm{~min}$ and $270^{\circ} \mathrm{C}$ for $25 \mathrm{~min}$. The Inlet had the following characteristics: temperature of $250^{\circ} \mathrm{C}$, helium gas carrier, split flow of $20 \mathrm{ml} / \mathrm{min}$, splitless split/splitless inlet: splitless injection mode, $60.688 \mathrm{kPa}$ as inlet pressure, $50 \mathrm{ml} / \mathrm{min}$ and $2 \mathrm{~min}$ for purge flow and time, respectively; gas saver on and $20 \mathrm{ml} / \mathrm{min}$ for gas saver flow and $2 \mathrm{~min}$ for gas saver time. In this analysis, the used MS had the following specifications: ms quadrupole at $150^{\circ} \mathrm{C}$, from 50 to $550 \mathrm{~m} / \mathrm{z}$ full scan, $70 \mathrm{eV}$ ion ionized energy, source and transfer line temperature at $250^{\circ} \mathrm{C}$. The volatile compounds were identified by reference to mass spectra and the retention time of Wiley09 NIST2011 library.

\section{Results and Discussion}

\section{Sludge characterization}

The main characteristics of the collected sludge are summarized in Table 1. The results reveal that the mean value of 7.15 for $\mathrm{pH}, 11200 \mathrm{mg} \mathrm{O}_{2} / \mathrm{L}$ for COD and $16 \mathrm{~g} / \mathrm{L}$ for SS. VSS content was $2.6 \mathrm{~g} / \mathrm{L}$, the TOC was about $473 \mathrm{mg} / \mathrm{kg}$ and the ammonical nitrogen and phosphorus contents were $400 \mathrm{mg} / \mathrm{L}$ and $6.53 \mathrm{mg} / \mathrm{kg}$ respectively. Compared to a similar sludge reported in Ramirez et al. 2018, we observed a low carbon-nitrogen content of Tunisian sludge and quite high level of COD which might be attributed to the industrial effluent co-treated at the Chotrana wastewater treatment plant. 


\section{Aloe sp. gel characterization}

In order to provide meaningful discussion on the effect of the bio-flocculants on the sludge treatment, the Aloe sp. leaf gel characteristics were determined (Table 2). The analysis revealed an important amount of soluble sugars of about $22.8 \mathrm{~g} / 100 \mathrm{~g}$ of lyophilized gel and high content of proteins $(7.8 \mathrm{~g} / 100 \mathrm{~g})$. Fats minerals and metals were also detected.

\section{Treatment of sludge with Aloe gel and water glass}

\section{Effect of Alg and water glass addition on sludge's pH}

Fig.1 illustrates the effect of the Aloe sp. gel (Alg) addition on the sludge's pH. The figure also shows the effect of adding water glass (WG) alone or combined with Alg (Alg-WG) on $\mathrm{pH}$ values. Following the addition of $3 \mathrm{~mL} / 100 \mathrm{~mL} \mathrm{Alg}$, the $\mathrm{pH}$ showed only a modest increase from 6.95 to 7.9 to remain constant at 7.9 regardless of the increased amount of Alg added. However, the addition of $3 \mathrm{~mL} / 100 \mathrm{~mL}$ water glass exhibited a remarkable increase in $\mathrm{pH}$ from 6.95 to 12.5 . A further increase in WG has increased $\mathrm{pH}$ modestly to reach a value of $\mathrm{pH} 13$ after adding $7 \mathrm{~mL} / \mathrm{L}$ of water glass. In fact, the alkaline character of sodium silicate is the main cause of $\mathrm{pH}$ increase as shown by the reaction equation:

\section{Effect on turbidity removal}

Fig.2 shows the turbidity changes versus the added volumes of Alg and WG separately and in combination. The results show that as the added volume increases, the turbidity decreases. According to Fig 3, Alg was less effective than water glass to remove turbidity (Alg: 45\%; WG: $89 \%$ ). This could be attributed to the formation of calcium silicate as main precipitate following the reaction of water glass (sodium silicate) and calcium content in the sludge (Table 1). The 
obtained precipitate had a potential to adsorb fine particles making the supernatant free of particles.

\section{Effect of Alg and WG addition on SS and VSS}

Fig.3 illustrates the effect of the different doses of Aloe gel and water glass added separately or in combination on both SS and VSS removal. The obtained results show that the SS content increased instead of being reduced. However, no significant effect was noticed for VSS removal with both treating agents used separately or combined. The progressive addition of WG in the sludge at contents higher than $1 \%$ induced a reestablishment of the SS content to its original value $(\sim 20.3 \mathrm{~g} / \mathrm{L})$ after a drop to $14.5 \mathrm{~g} / \mathrm{L}$ at $1 \% \mathrm{WG}(\mathbf{F i g} .3 \mathbf{b})$. In order to investigate the combined effect of Aloe gel and WG addition on the sludge treatability, further experiments were carried out at fixed Alg content of 3\% while WG dosages were varied from 1 to $7 \%$. The more WG was added, the higher the SS content was recorded (ranging from $20.4 \mathrm{~g} / \mathrm{L}$ at $1 \% \mathrm{WG}$ dosage to reach $27.5 \mathrm{~g} / \mathrm{L}$ at $7 \% \mathrm{WG}$ ). The VSS values recorded a moderate increase from $9 \mathrm{~g} / \mathrm{L}$ at $1 \%$ to $10 \mathrm{~g} / \mathrm{L}$ at $7 \%$ (Fig. $3 \mathbf{c}$ ).

\section{Effect of Alg and WG addition on COD and $\mathrm{NH}_{4}-\mathrm{N}$}

Fig. 4 illustrates the changes of COD and ammonia nitrogen concentrations with the added volume of Aloe gel and water glass separately and combined. At low doses, the recorded data reveal a slight increase of COD value when aloe gel was added to the sludge (Fig. 4a). Similar observations were also reported by Ramavandi and Farjadfard (2014). This increase in COD following the addition of Alg was expected due to the organic matter content of Aloe gel which is rich in organic substances (e.g. carbohydrates and proteins). Yet, above $1 \mathrm{~mL} / 100 \mathrm{~mL}$ of added Alg, the COD values of the solution showed a decreasing trend but the overall COD of the solution remains higher than the initial COD of the sludge until the applied dose of Alg exceeded $5 \mathrm{~mL} / 100 \mathrm{~mL}$ Alg. A further increase in $\mathrm{Alg}$ doses above $5 \mathrm{~mL} / 100 \mathrm{~mL}$, results in COD values slightly lower than the original COD value of the sludge. In contrast, the addition 
of WG alone or combined with Alg resulted in a much more effective COD removal than Alg reaching a removal percentage of about $25 \%$ at a dose of $7 \mathrm{~mL} / 100 \mathrm{~mL}$ water glass.

Fig. 4b shows the removal of $\mathrm{NH}_{4}{ }^{+}-\mathrm{N}$ at different doses of Alg and WG. According to Fig. 5b, the addition of Alg and WG alone or combined at low doses resulted in a significant reduction in ammonia. At a dose of $1 \mathrm{~mL} / 100 \mathrm{~mL}$, the removal of $\mathrm{NH}_{4}{ }^{+}-\mathrm{N}$ was $66 \%$ for all agents to reach $89 \%$ at $7 \mathrm{~mL} / 100 \mathrm{~mL}$ WG. A further increase in Alg dose above $1 \mathrm{~mL} / 100 \mathrm{~mL}$ did not increase $\mathrm{NH}_{4}{ }^{+}-\mathrm{N}$ removal but it made it worst (only $40 \%$ removal at $7 \mathrm{~mL} / \mathrm{L}$ ), possibly due to a competition with COD removal as illustrated in Fig. 4a where COD removal with aloe gel becomes relevant only at high doses. In addition, Alg active constituents (e.g. proteins) may aggregate and fold at high doses (Gupta et al. 1998), which reduces the number of active functional groups available for $\mathrm{NH}_{4}{ }^{+}$accumulation and adhesion. The action of water glass was much more pronounced since its alkali character changes ammonium to ammonia $\operatorname{gas}\left(\mathrm{pKa}=9.25\right.$ at $\left.25^{\circ} \mathrm{C}\right)$ that can be easily removed from solution via the increase of $\mathrm{pH}$ to 12.9

(Fig. 1); which justifies the high ammonia removal of $89 \%$ obtained following the addition of WG.

\section{Performances of Aloe gel and water glass on sludge settling}

Fig. 5 depicts the sludge settling performance for Alg and for combined Alg-WG treatments as well as the raw sludge without any coagulant being added. The SVI values are also indicated in Fig.5. The combined Alg-WG treated sample exhibited a net drop from $100 \mathrm{~mL}$ to reach $15 \mathrm{ml}$ within only $5 \mathrm{~min}$. The settled volume stabilized at $10 \mathrm{ml}$ after $10 \mathrm{~min}$ until the end of the experiment (90 min). The Alg treated sample settled volume was limited to $28 \mathrm{~mL}$ after $40 \mathrm{~min}$ or higher settling times. However, it is noteworthy that both Alg and combined treatments recorded better results compared to the settling of raw samples without addition of any of the coagulants; where, at best, a final settling sludge volume of $34 \mathrm{~mL}$ was recorded after 80 
minutes settling. The effect of the optimal dosages of the combined treatment of sludge after settling using 3\% of Alg and 3\% of WG dosages showed a net difference of settling rates.

Fig .6 gives the particle size distribution of the untreated sludge, sludge with Aloe gel and sludge with both Aloe gel and water glass. Particle size shifts are clearly observed for the Alg-WG treated sludge. The sludge particles shifted from fine sizes $(\sim 100 \mu \mathrm{m})$ to larger particles and the agglomerates were found to have a bimodal distribution with a mean size value of $300 \mu \mathrm{m}$. This might explain the accelerated settling velocity observed in the presence of WG. The increased particle size as a result of WG addition could be explained by the formation of large aggregates resulting from the interaction between silicate polymers (i.e. WG) and sludge with possible ion binding with inorganics in the wastewater (e.g. $\mathrm{Ca}^{2+}$ ) (Okano et al. 2015; Zuo et al. 2015) .

The SEM images (Fig. 7) show that the structures of the raw sludge and the treated sludge with Alg-WG have an abundance of micro pores. The SEM images suggest that significant changes in the floc's morphology occurred following the addition of Alg-WG as evidenced by the formation of large aggregates showing pillars of 10 to $20 \mu \mathrm{m}$ of length between aggregates in the presence of Alg-WG. The observed building structure might be attributed to calcium silicate due to the reaction of silicates in the water glass with calcium in the sludge (Okano et al. 2015). The outcome of this novel combined treatment of wastewater sludge by addition of Aloe gel and water glass highlighted the clear macroscopic aspect of coarse agglomerates of sludge with raw sludge having suspended fine particles.

\section{Performances of Aloe gel on sludge odour removal}

The mass spectrum of VOCs emitted by the untreated sludge is illustrated in Fig. 8a. The analysis allowed the detection of four compounds identified as Toluene (peak 1), Benzenamine, N-ethyl- (peak 2), 4-fluoro-1,2-xylene (peak 3) and phenol, 2,6-bis(1,1-dimethylethyl) (peak 4) with retention times (min) of 5.087, 12.394, 13.415 and 17.981 and relative areas (\%) of 41.03, 38.34, 12.76 and 7.86, respectively. Fig. $8 \mathbf{b}$ and $\mathbf{c}$ illustrate the mass spectra of VOCs emitted 
by the treated sludge using Alg and WG, respectively. The spectra show that the addition of either Alg or WG results in the disappearance of peaks 2, 3 and 4 initially detected among the untreated sludge VOCs. Nevertheless, a new compound identified as D-limonene with retention time (min) of 9.867 and relative area of $48.64 \%$ was detected after Alg addition. Limonene is one of the most widespread terpenes in the flavour and fragrance industry (Zodi et al. 2009). A human olfactory sensing experiment was carried out and showed that the twenty people did not detect any unpleasant smell from the treated sludge, which provides a further evidence of the removal of odour following the application of Alg.

\section{Conclusion}

This study presented a new insight of the potential use of Aloe gel for the treatment of municipal wastewater sludge as a novel bioflocculant. Aloe sp. leaf gel, at different doses (1, 3, 5 and 7\%), was tested as bioflocculant via sequential treatments that used coagulation, flocculation and sedimentation processes under defined operating conditions. The Aloe gel showed good performance for sludge solid- liquid separation. To enhance the Aloe gel action, a further step was necessary by the addition of water glass. The combined treatment showed that the use of aloe gel and water glass at $3 \%$ yielded a removal of turbidity up to $83 \%$, and $89 \%$ of ammonia nitrogen. Moreover, the resulting flocs from the treatment using aloe gel and water glass generate much coarser particles and readily settling sludge, typically with only 5 min of settling time. SEM investigation enabled the observation of multi pillars of 10 to $20 \mu \mathrm{m}$ length located within the sludge intra particles. Furthermore, the Aloe leaf gel odour removal efficiency was revealed through VOCs analysis of the treated sludge which indicated the disappearance of odour-causing substances following application of Aloe gel or water glass. The proposed process would be an attractive approach not only to reduce the treatment cost but also to minimize environmental concerns and generate eco-friendly sludge. 


\section{References}

Abdelaal A.M. 2004 Using a natural coagulant for treating wastewater. Paper presented at the Eighth International Water Technology Conference Alexandria, Egypt.

Abid A., Zouhri A. \& Ider A. 2009 Utilisation d'un nouveau bio- floculant extrait de cactus marocain dans le traitement des rejets chargés de chrome(VI) par le procédé de coagulation floculation Afrique Sciences, 5, 25-35

Adugna A.T. \& Gebresilasie N.M. 2018 Aloe steudneri gel as natural flocculant for textile wastewater treatment. Water Practice and Technology, 13, 495-504.

AFNOR 1999 Protocol d'évaluation d'une méthode alternative d'analyse physicochimique quantitative par rapport à une méthode de référence, T90-210 AFNOR, Paris.

AL-Sameraiy M. 2012 A Novel Water Pretreatment Approach for Turbidity Removal Using Date Seeds and Pollen Sheath. Journal of Water Resource and Protection, 4, 79-92.

Al-Samawi A.A. \& Shokralla E.M. 1996 An investigation into an indigenous natural coagulant. Journal of Environmental Science and Health Part A: Environmental Science and Engineering and Toxicology, 31, 1881-1897.

Bouaoun I., Hammi H., Aït-Mokhtar A., El Amine Hamami A. \& M'nif A. 2017 Effect of calcination temperature of magnesium silicate on the properties of magnesium phosphate cement. Journal of the Australian Ceramic Society, 53, 351-359.

Bradford M. 1976 A Rapid and Sensitive Method for the Quantitation of Microgram Quantities of Protein Utilizing the Principle of Protein-Dye Binding. Analytical Biochemistry, 72, 248-256

Dubois M., Gilles K.A., Hamilton J.K., Rebers P.A. \& Smith F. 1956 Colorimetric Method for determination of sugars and related substances. Analytical Chemistry, 28, 350-356.

Eugene S., Nidiry J., Girija G., Lokesha A. 2011 Antifungal Activity of Some Extractives and Constituents of Aloe vera. Research Journal of Medicinal Plants, 5, 196-200.

Femenia A., Sánchez E.S., Simal S. \& Rosselló C 1999 Compositional features of polysaccharides from Aloe vera (Aloe barbadensis Miller) plant tissues. Carbohydrate Polymers, 39, 109-117

Giri S.S., Harshiny M., Sen S.S., Sukumaran V. \& Park S.C. 2015 Production and characterization of a thermostable bioflocculant from Bacillus subtilis F9, isolated from wastewater sludge. Ecotoxicology and environmental safety, 121, 45-50.

Gupta P., Hall C.K. \& Voegler A.C. 1998 Effect of denaturant and protein concentrations upon protein refolding and aggregation: a simple lattice model. Protein science : a publication of the Protein Society, 7, 2642-2652

Hamman J.H. 2008 Composition and applications of Aloe vera leaf gel. Molecules, 13, 1599-1616

Jemli M., Sabbahi S. \& Ben Ayed L. 2015 Performance of Urban Wastewater Treatment of Four Activate Sludge Treatment Plants in Tunisia. International Journal of Water and Wastewater Treatment, 1, 1-4.

Kallel A., Attour A. \& Trabelsi I. 2017 Electro-coagulation treatment of raw and autoclaved landfill leachate with aluminum electrodes: case study of Djebel Chakir (Tunisia). Arabian Journal of Geosciences, 10, 85-92

Kasmi M., Elleuch L., Abidi H., Cherni Y., Hosni C., Nouioui S., Fattouch S. \& Trabelsi I. 2018 Use of dairy reject and fermented Aleo sp. Leaf Gel mixture in the biological Pre-treatment of landfill leachate. Water Practice and Technology, 13, 219-228 
Lee K.E., Hanafiah M.M., Halim A.A. \& Mahmud M.H. 2015 Primary Treatment of Dye Wastewater Using Aloe Vera-aided Aluminium and Magnesium Hybrid Coagulants. Procedia Environmental Sciences, 30, 56-61

Liu C., Wang K., Jiang J-H., Liu W-J. \& Wang J-Y. 2015 A novel bioflocculant produced by a salttolerant, alkaliphilic and biofilm-forming strain Bacillus agaradhaerens $\mathrm{C} 9$ and its application in harvesting Chlorella minutissima UTEX2341. Biochemical Engineering Journal 93, 166-172

Liu W, Wang K, Li B, Yuan H, Yang J 2010 Production and characterization of an intracellular bioflocculant by Chryseobacterium daeguense W6 cultured in low nutrition medium. Bioresource Technology, 101, 1044-1048

Mandloi M., Chaudhari S. \& Folkard G.K. 2004 Evaluation of natural coagulants for direct filtration. Environmental Technology, 25, 481-489

Mazzulla S., Sesti S., Schella A., Perrotta I., Anile A. \& Drogo S. 2012 Protective Effect of Aloe vera (Aloe barbadensis Miller) on Erythrocytes Anion Transporter and Oxidative Change. Food and Nutrition Sciences, 3, 1697-1702

Menkiti M.C. \& Onukwuli O.D. 2010 Coag-Flocculation of Moringa Oleifera Coagulant (MOC) in Brewery Effluent: Nephelometric Approach. Journal of American Science, 6, 788-806.

Nougbode Y.A.E.I., Agbangan C.P., Koudoro A.Y., Dèdjiho C.A., Aïna M.P., Mama D. \& Sohounhloue D.C.K. 2013 Evaluation of the Opuntia dillenii as natural Coagulant in water Clarification: Case of treatment of Highly Turbid Surface Water. Journal of Water Resource and Protection, $\mathbf{5}$, $1242-1246$.

Nougbode Y.A.E.I., Sessou P., Alassane A., Youssao A.K.A., Agbangna C.P., Mama D. \& Sohounhloue K.C.D 2016 Evaluation of Aloe vera leaf gel as a Natural Flocculant: Phytochemical Screening and Turbidity removal Trials of water by Coagulation flocculation. Research Journal of Recent Sciences, 5, 9-15.

Nowak O. 2006 Optimizing the Use of Sludge Treatment Facilities at Municipal WWTPs. Journal of Environmental Science and Health (Part A), 41,1807-1817.

Okano K., Miyamaru S., Kitao A., Takano H., Aketo T., Toda M., Honda H. \& Ohtake H. 2015 Amorphous calcium silicate hydrates and their possible mechanism for recovering phosphate from wastewater. Separation and Purification Technology, 144, 63-69.

Pati C. \& Hugar M. 2015 Treatment of dairy wastewater by natural coagulants. International Research Journal of Engineering and Technology, 2, 1120-1125.

Radha M.H. \& Laxmipriya N.P. 2015 Evaluation of biological properties and clinical effectiveness of Aloe vera: A systematic review. Journal of Traditional and Complementary Medicine, 5, 2126.

Ramavandi B. \& Farjadfard S. 2014 Removal of chemical oxygen demand from textile wastewater using a natural coagulant. Korean Journal of Chemical Engineering, 31,81-87.

Ramirez K., Possan E., Bittencourt P., Carneiro C. \& Colombo M. 2018 Physico-chemical characterization of centrifuged sludge from the Tamanduá water treatment plant. Matéria (Rio J), 23 doi:10.1590/s1517-707620180003.0521

Rodier J., Legube B., Merlet N. \& Brunet R. 2009 Eaux Résiduaires. In: L'analyse de l'eau: Eaux naturelles, eaux résiduaires, eau de mer. Rodier J (ed), Dunod, Paris. pp. 987-991.

Shilpa B.S., Akanksha K. \& Girish P. 2012 Evaluation of Cactus and Hyacinth Bean Peels as Natural Coagulants. International Journal of Chemical and Environmental Engineering, 3, 187-191.

Tchobanoglous G., Burton F.L. \& Stensel H.D. 2003 Wastewater Engineering: Treatment and Reuse. $4^{\text {th }}$ edn. Metcalf \& Eddy Inc, New York. 
Zahrim A.Y., Tizaoui C. \& Hilal N. 2010 Evaluation of several commercial synthetic polymers as flocculant aids for removal of highly concentrated C.I. Acid Black 210 dye. Journal of hazardous materials, 182, 624-630.

Zodi S., Potier O., Lapicque F. \& Leclerc J-P. 2009 Treatment of the textile wastewaters by electrocoagulation: Effect of operating parameters on the sludge settling characteristics. Separation and Purification Technology, 69, 29-36.

Zuo M.Y., Renman G., Gustafsson J.P. \& Renman A. 2015 Phosphorus removal performance and speciation in virgin and modified argon oxygen decarburisation slag designed for wastewater treatment. Water Research, 87, 271-281. 


\section{Figure Captions}

436

437 Fig. $1 \mathrm{pH}$ values variation following the Aloe sp. leaf gel (Alg), water glass and aloe + water glass addition to sludge at different volume.

439 Fig. 2 Turbidity variation with different volume of Aloe sp. leaf gel (Alg), water glass and Aloe gel + water glass

Fig. 3 Variation of Suspend Solid (SS) and Volatile Suspended solid (VSS) of sludge following the application of (a) Aloe sp. leaf gel (Alg), (b) water glass and (c) aloe + water glass

Fig. 4 Variation of COD (a) and ammoniacal nitrogen (b) with volume of Aloe sp. leaf gel (Alg), water glass and Aloe + water glass

Fig. 5 Effect of Aloe gel ( $\square$ ) and combined Aloe gel-Water glass ( $\square$ ) addition on the treated sludge compared to the raw sample $(\square)$ during $90 \mathrm{~min}$

Fig. 6 Raw and treated sludge particle Master size distribution

Fig. 7 SEM image of raw sludge (a), and (b) combined Aloe gel and water glass treated sludge.

Fig. 8 Mass spectra of VOCs from the untreated sludge (a) and the treated sludge using Aloe 
462 Table 1 Characteristics of sludge generated by Chotrana municipal wastewater treatment plant.

\begin{tabular}{lcrc}
\hline Measured parameters & Unit & Recorded valu463 \\
\hline $\mathrm{pH}$ & - & 7.15 (at $\left.25^{\circ} \mathrm{C}\right)$ & 464 \\
Moisture content & $\%$ & $84 \pm 1$ & 465 \\
Dry matter content (SS) & $\%$ & $16 \pm 0.5$ & 466 \\
VSS & $\mathrm{g} . \mathrm{Kg}^{-1}$ & $2.6 \pm 0.5$ & 467 \\
TOC & $\mathrm{mg} . \mathrm{Kg}^{-1}$ & $473 \pm 5$ & 468 \\
Total nitrogen & $\mathrm{mg} . \mathrm{Kg}^{-1}$ & $33.2 \pm 0.5$ & 469 \\
Total phosphorous & $\mathrm{mg} . \mathrm{Kg}^{-1}$ & $6.53 \pm 0.05$ & 470 \\
COD & $\mathrm{mg} \mathrm{O} \mathrm{L}^{-1}$ & $11200 \pm 10$ & 471 \\
\hline
\end{tabular}

472

473

474 Table 2 Aloe leaf gel biochemical characterization

\begin{tabular}{lc}
$\begin{array}{l}\text { Lyophilized Aloe sp. leaf } \\
\text { gel constituent }\end{array}$ & $\begin{array}{c}\mathbf{4 7 5} \\
\mathbf{4 0 0 g}) \\
\text { Content }\end{array}$ \\
\hline Soluble sugars & 4.8 \\
Proteins & 22.78 \\
$\mathrm{Ca}$ & 7.82 \\
$\mathrm{Mg}$ & 3.02 \\
$\mathrm{Na}$ & 0.98 \\
$\mathrm{~K}$ & 3.03 \\
$\mathrm{P}$ & 3.89 \\
$\mathrm{Fe}$ & 0.01 \\
$\mathrm{Cu}$ & 0.87 \\
$\mathrm{Zn}$ & 0.04 \\
\hline
\end{tabular}


Figure 1

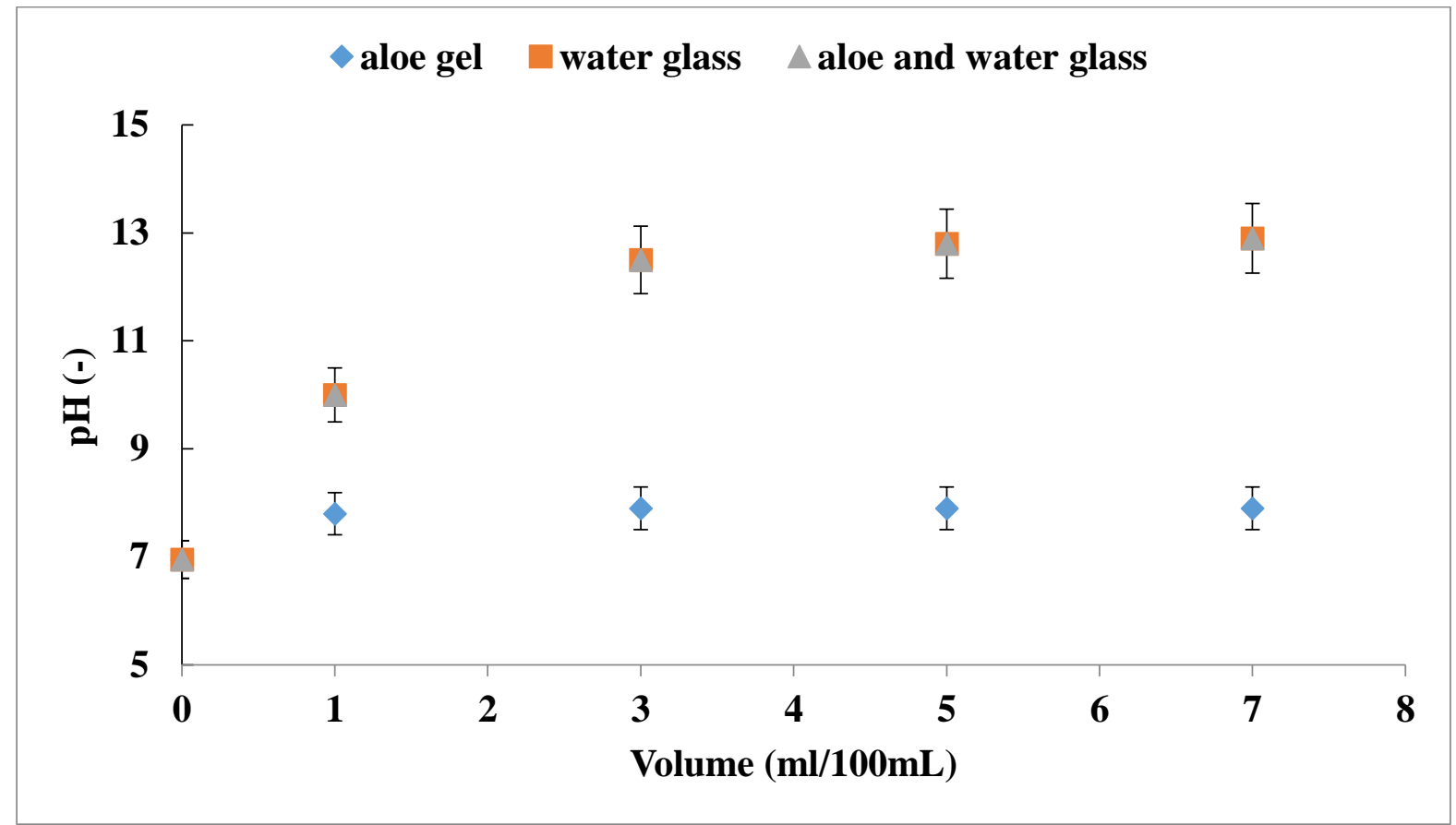

478

479

480

481

482

Figure 2

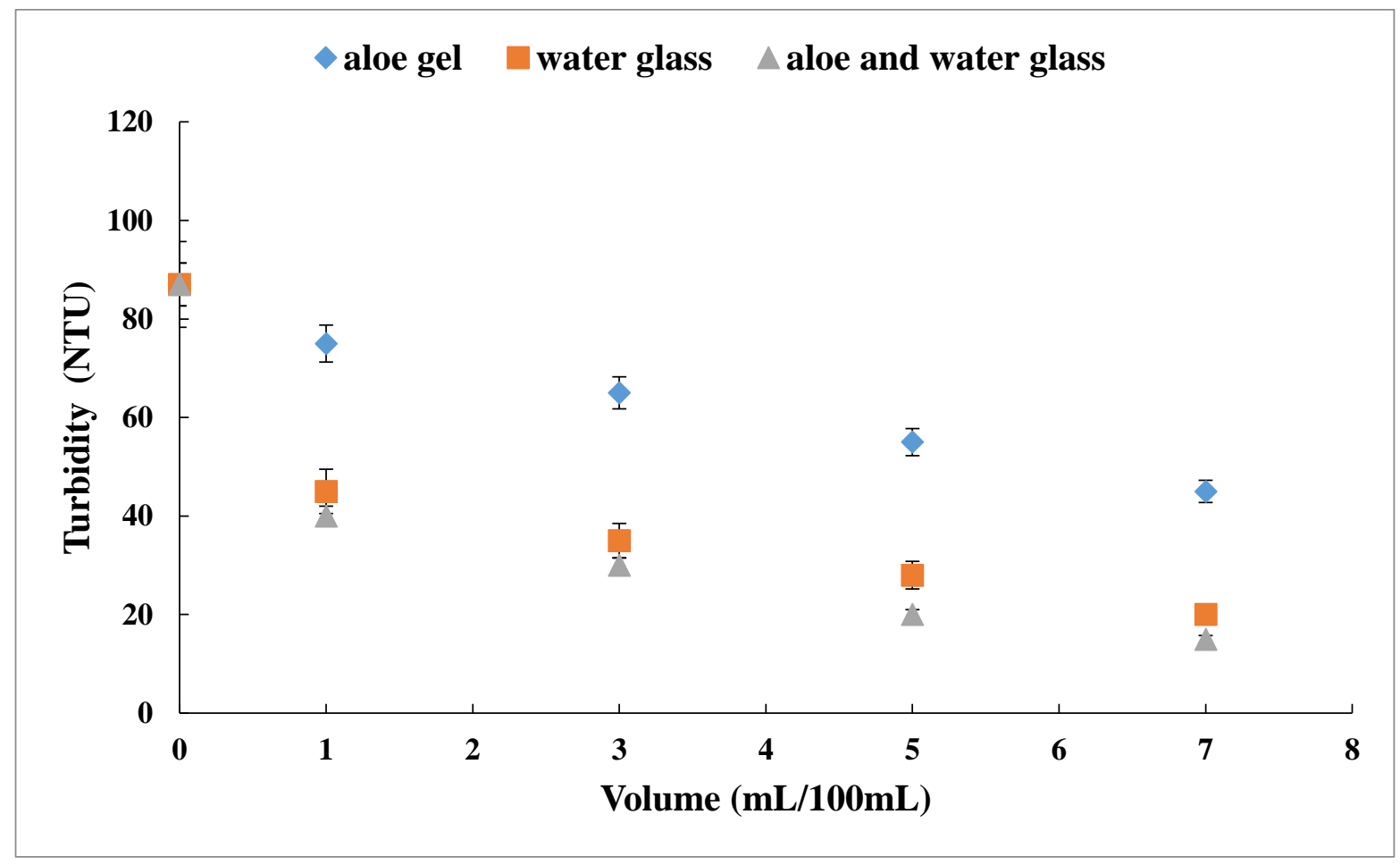

483

484 
Figure 3

487

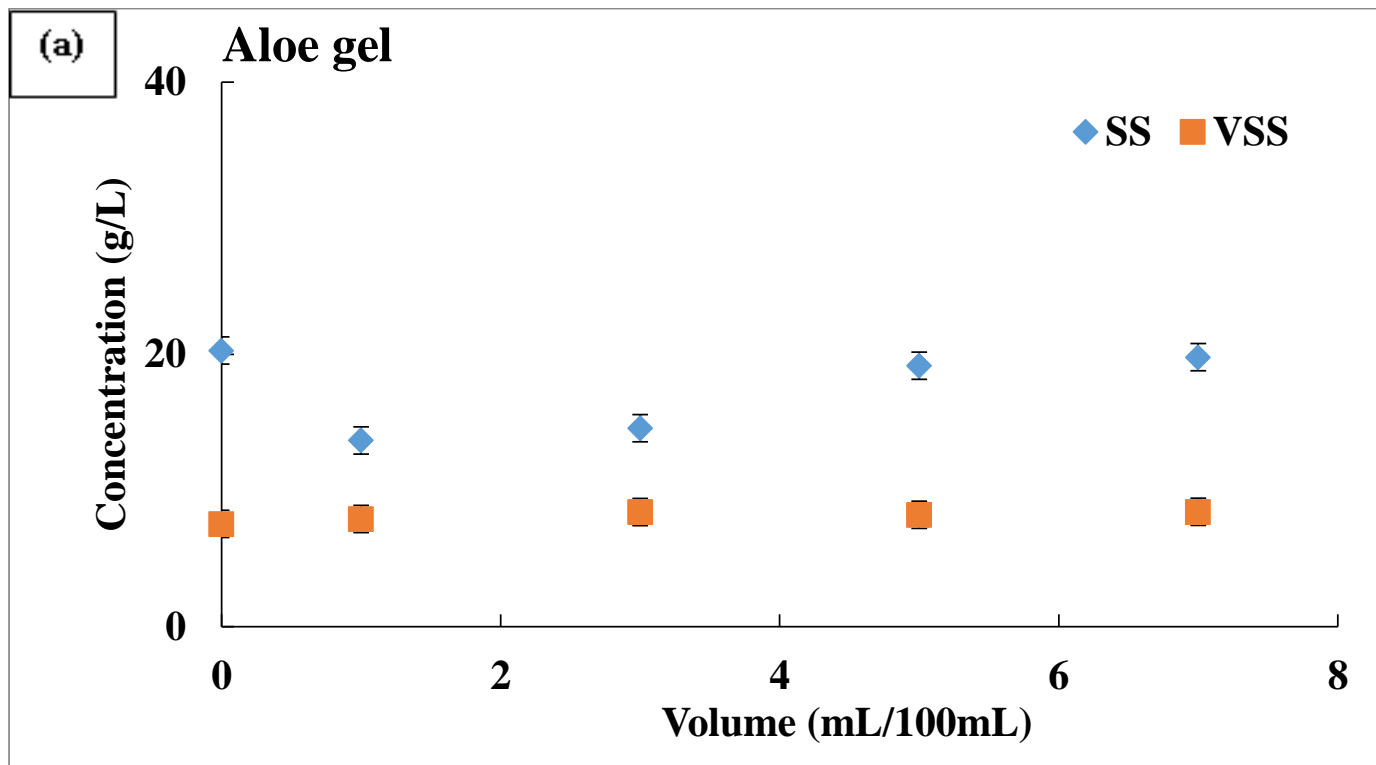

488
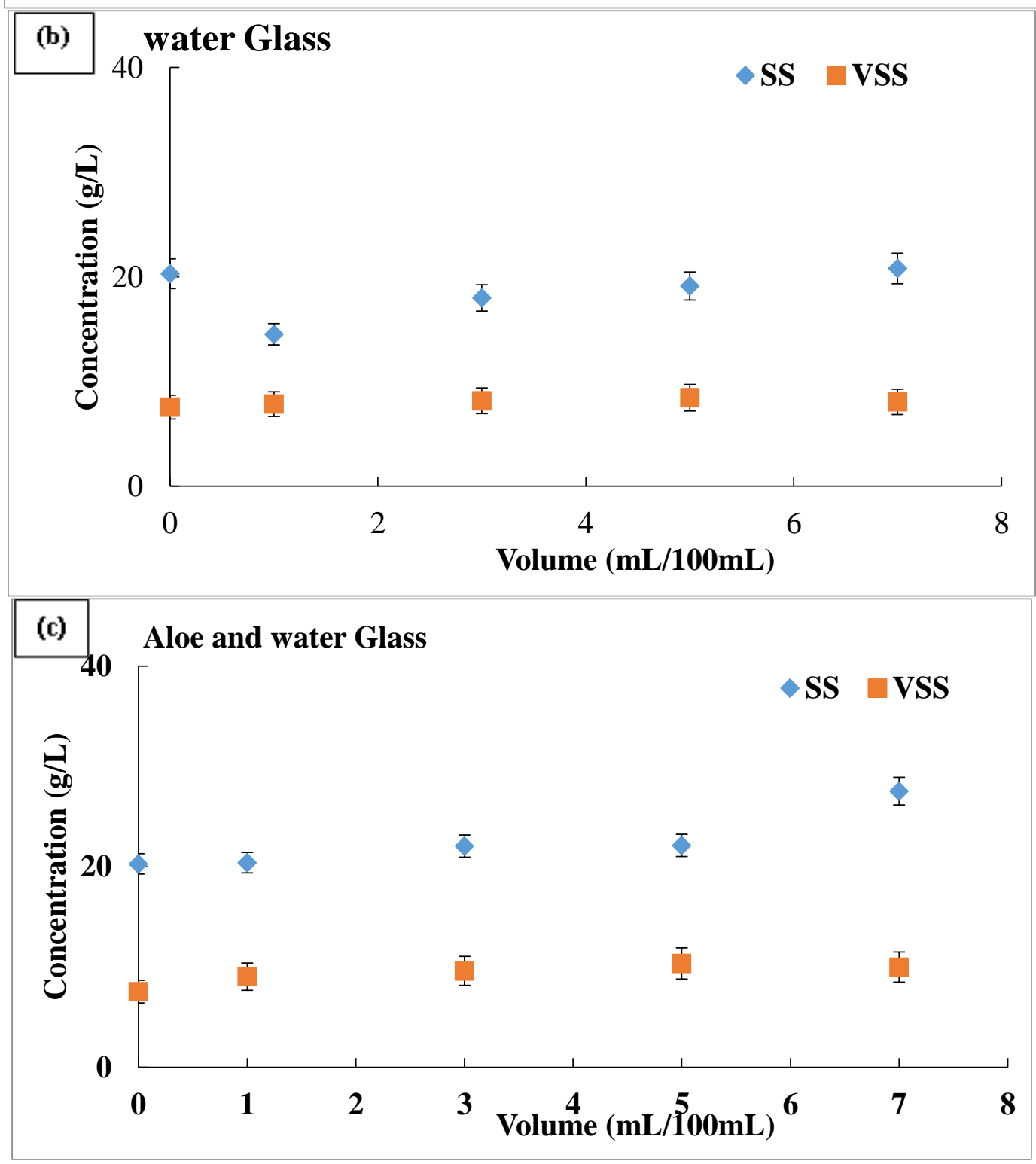
490

Figure 4

491

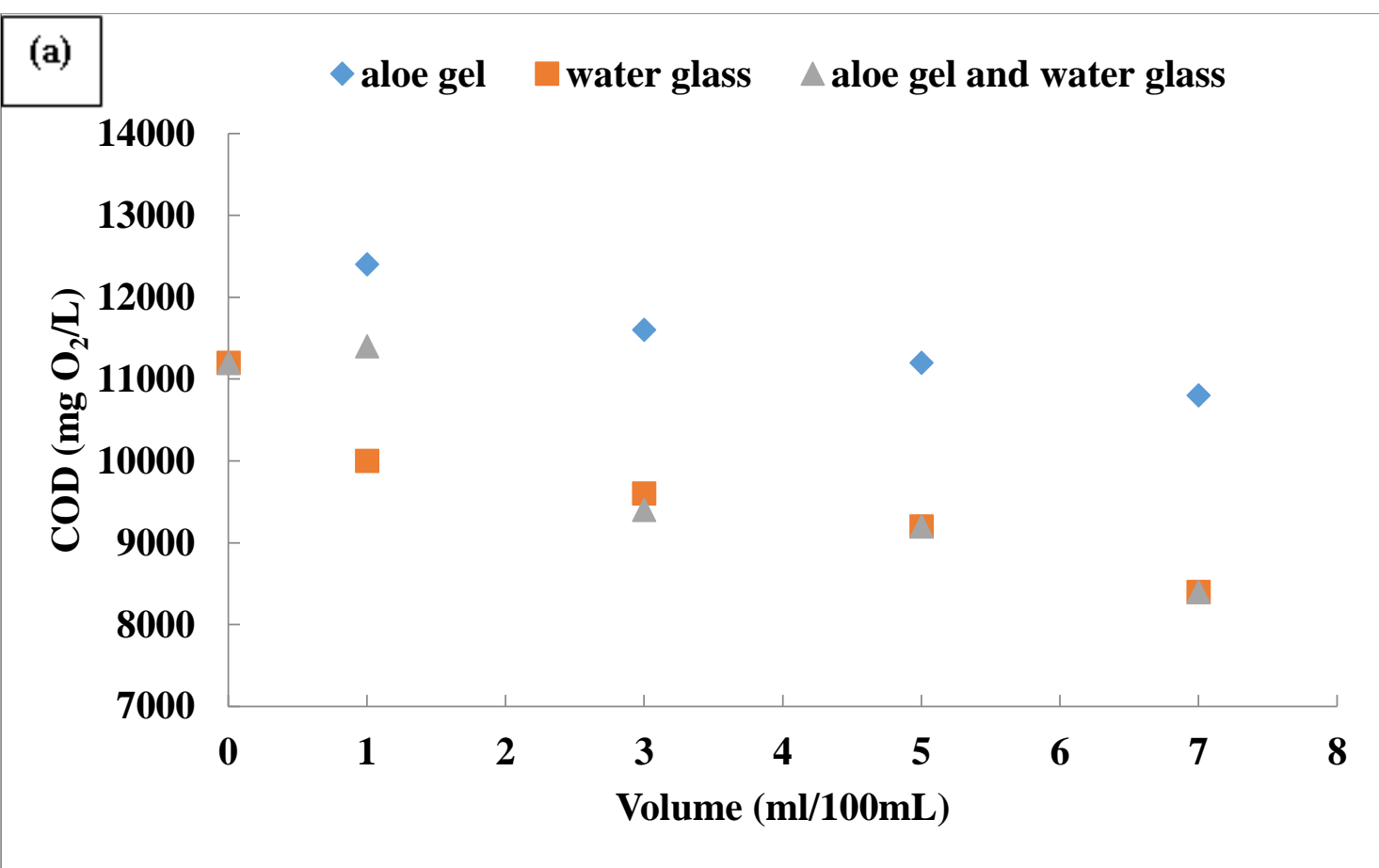

492

(b) aloe gel water glass $\triangle$ aloe and water glass

493

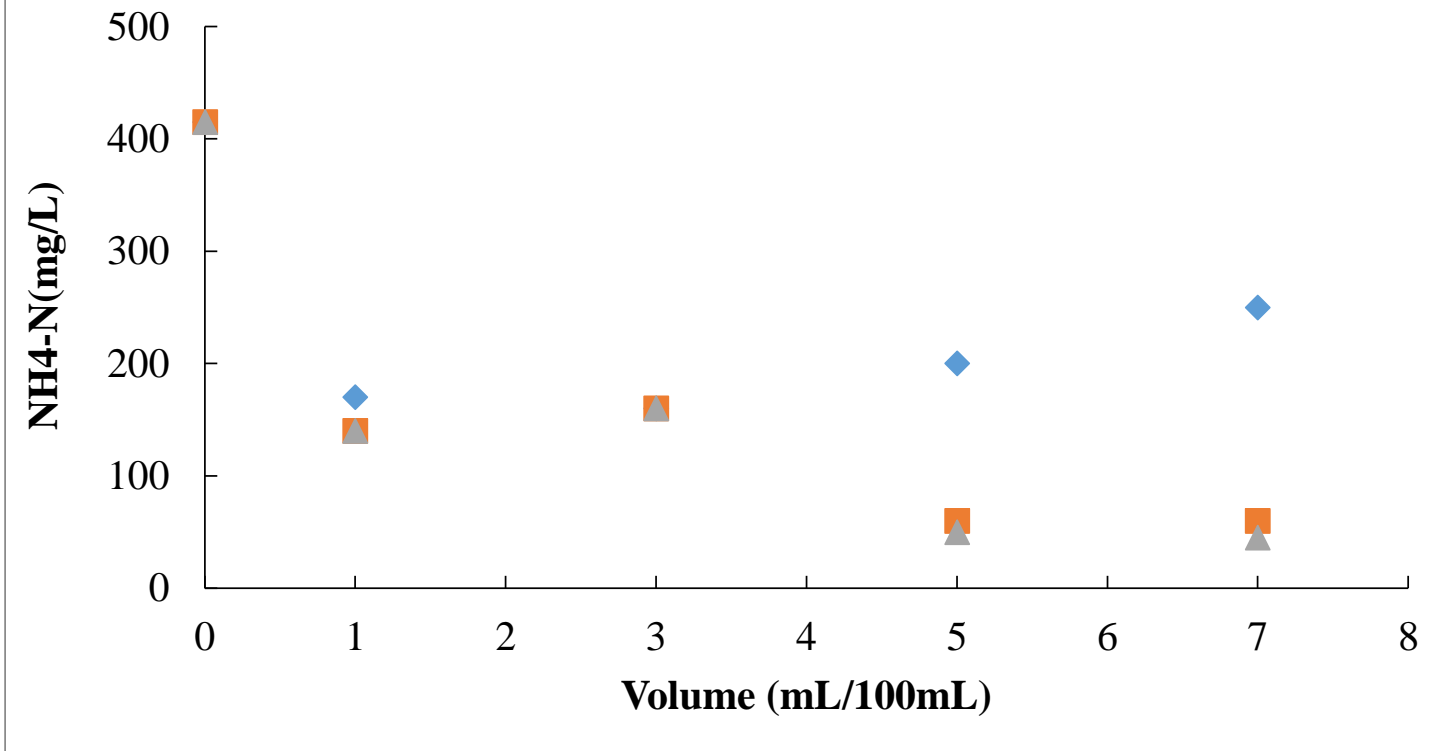

494

495

496

497

498

Figure 5 
Volume (ml)

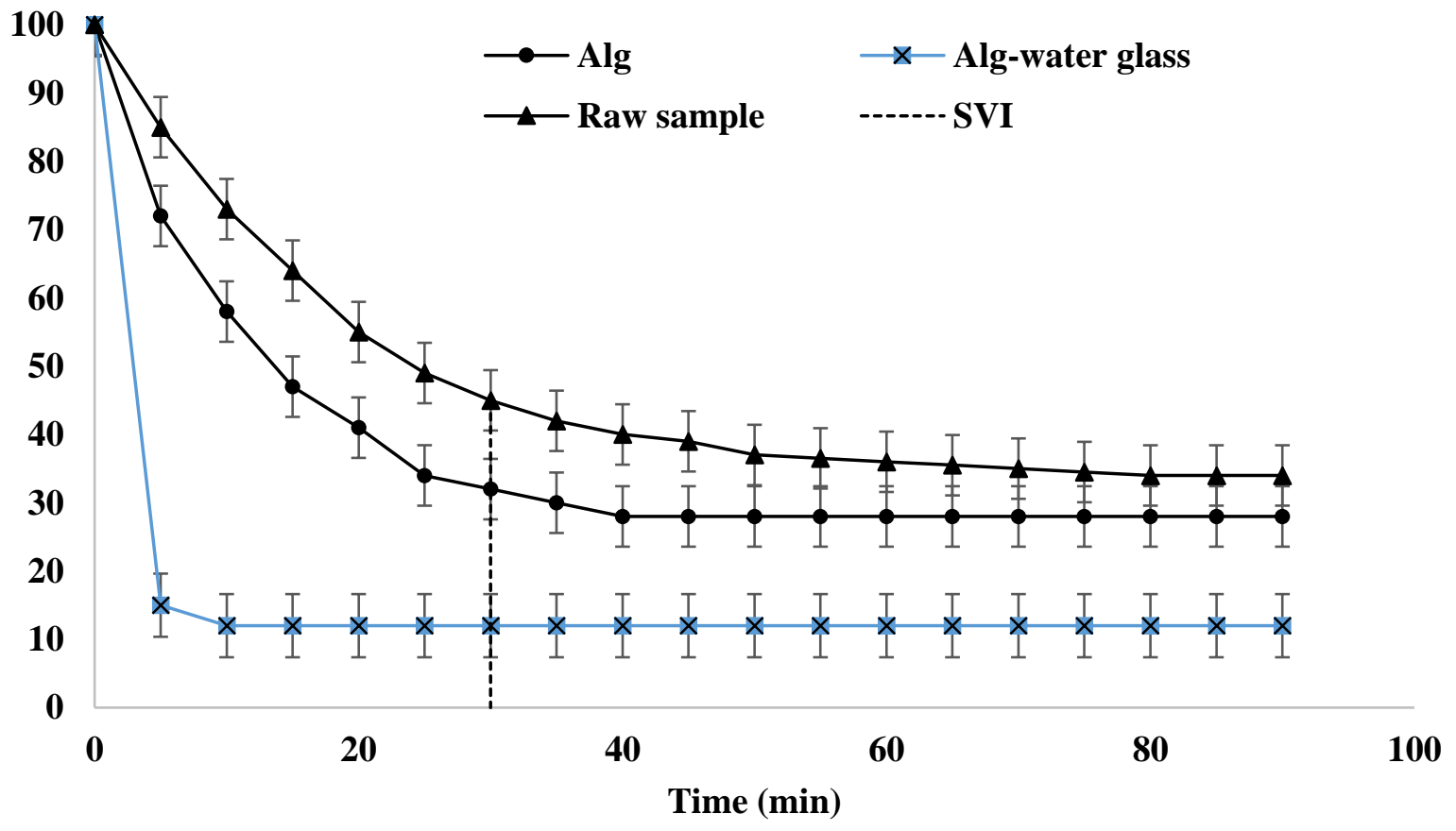

499

500

501

$502 \quad$ Figure 6

503

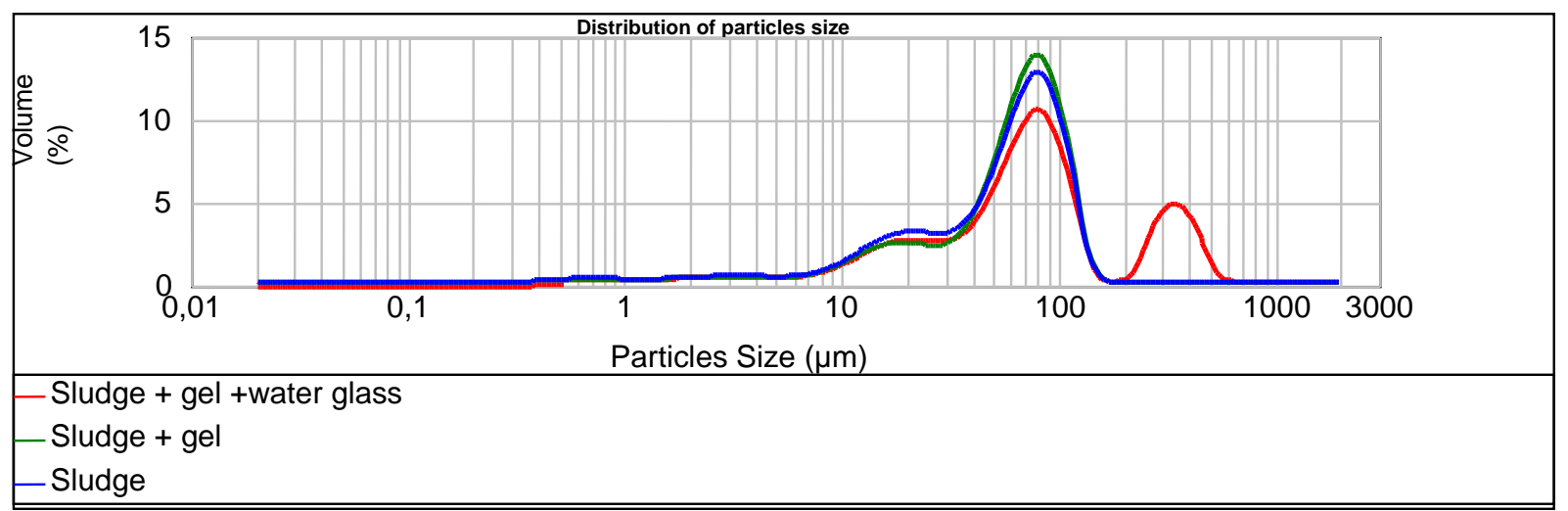

504

505 
Figure 7
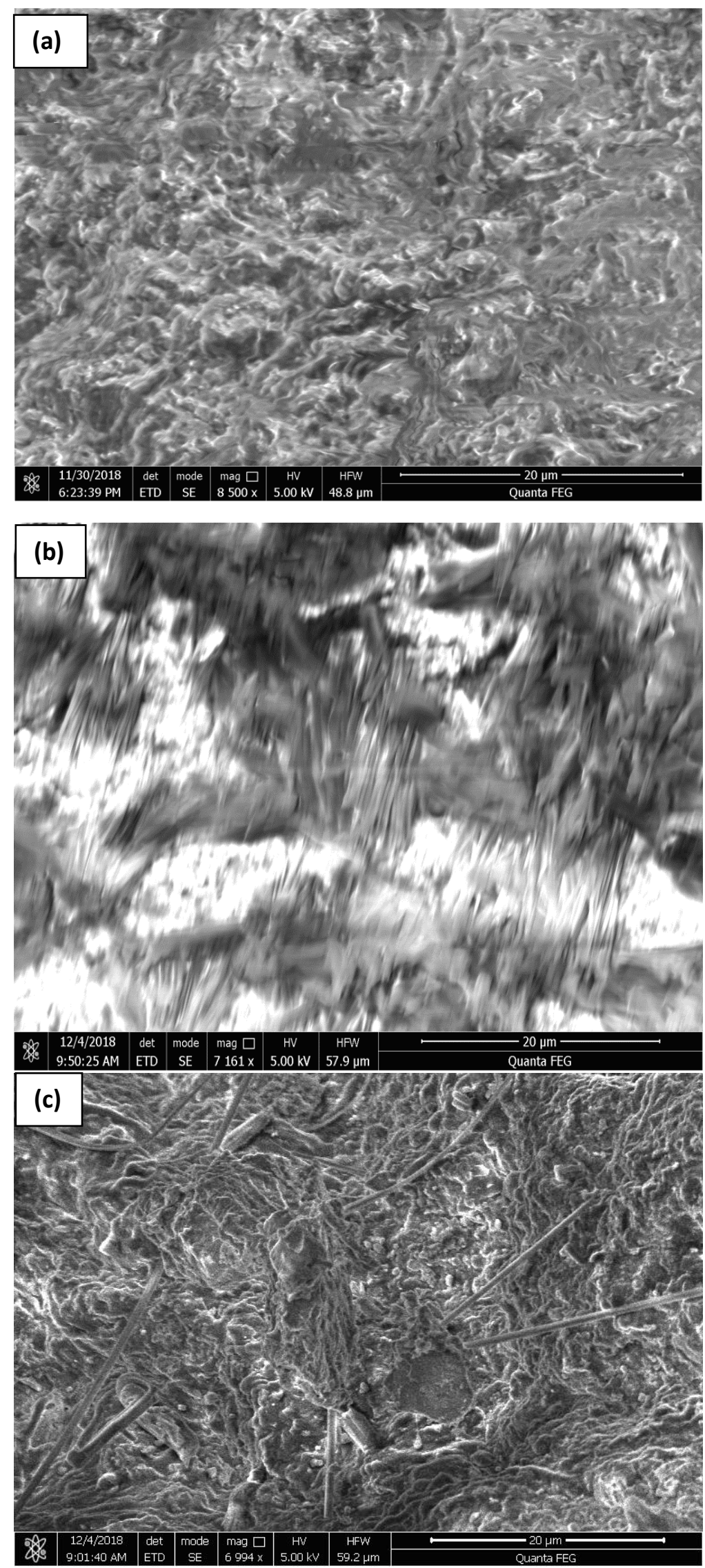
Abundance

60000

55000

50000

45000

40000

(a)
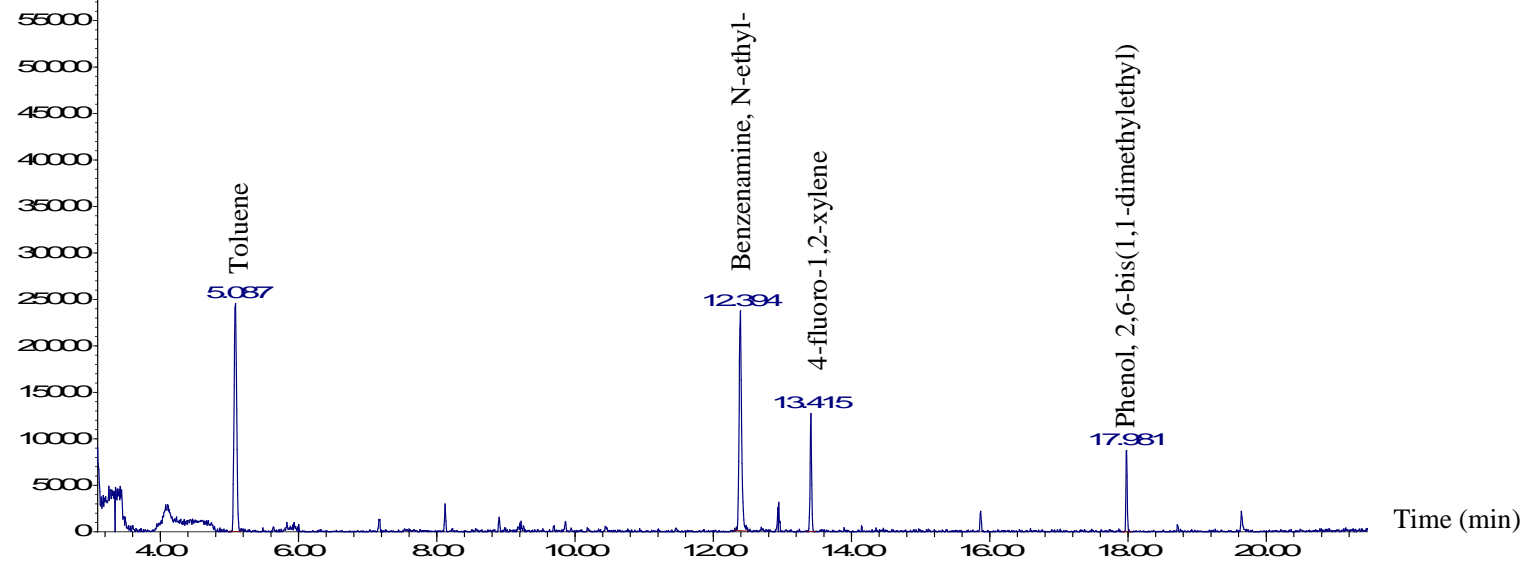

513

514

(b)

$$
\text { Abundance }
$$

$280000=$

$260000=$

240000

$220000=$

200000

180000

160000

140000

120000

80000

60000

40000

20000
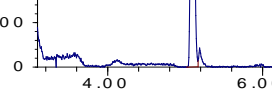

2.00

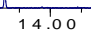

16.00

18.00

Time (min)

515

516

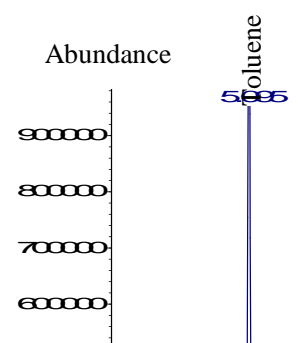

(c)
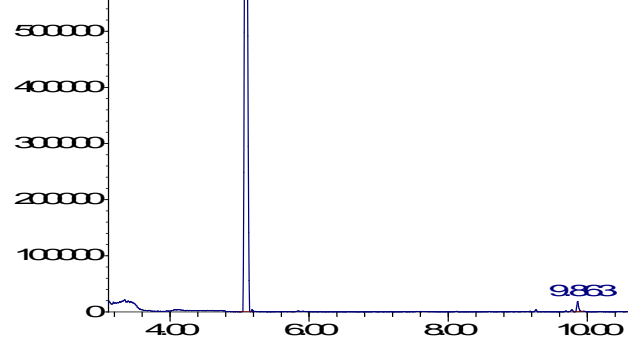

13414

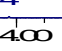


518 Figure S1: The untreated sludge (a) and the treated sludge using the combined Aloe gel and

519 sodium silicate at a dosage of $3 \%(\mathbf{b})$

520

521

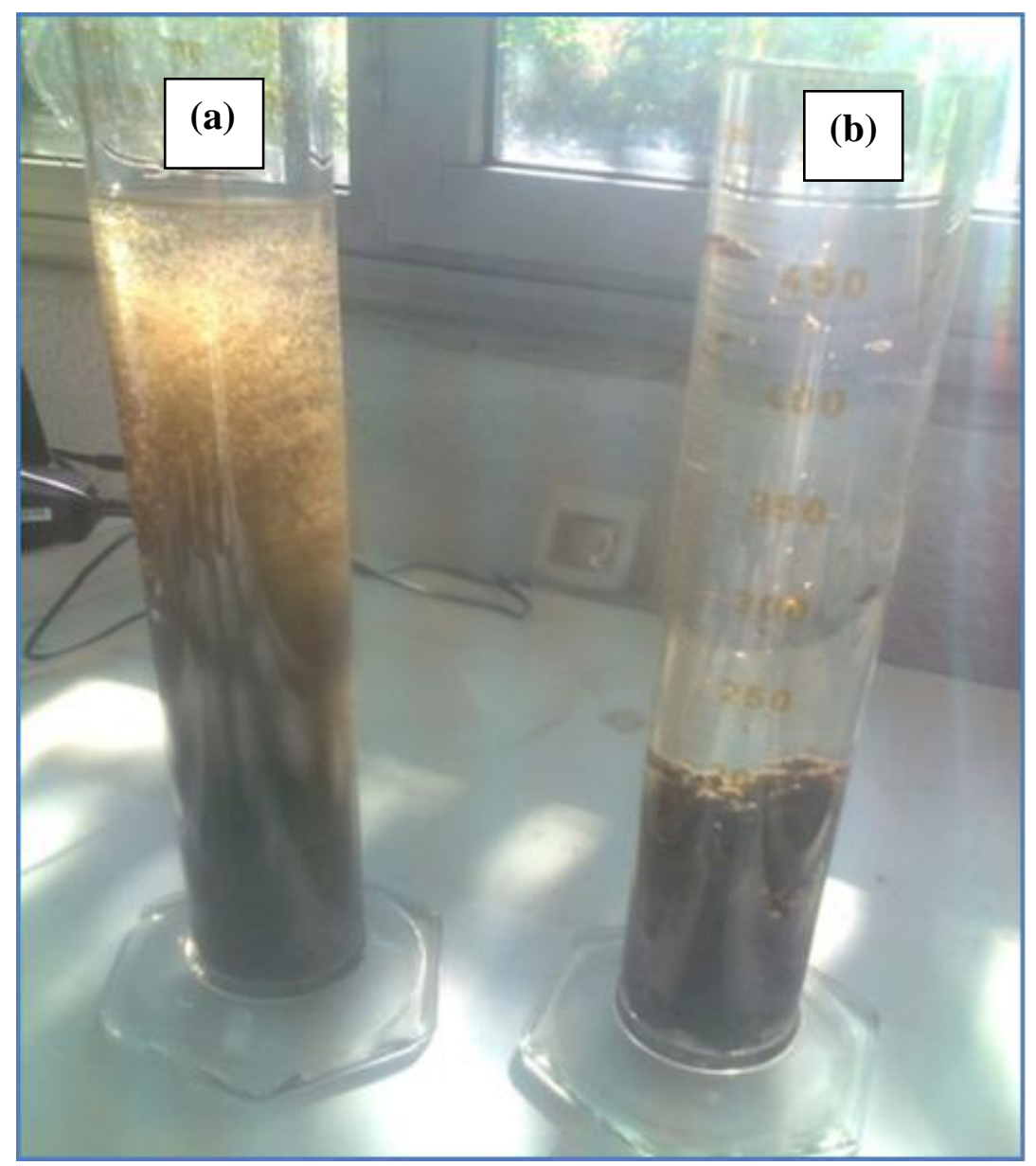

522

523

524

525 